patients. For these hysterical cases, sea air, sea bathing and swimming, together with games and gymnastic exercises, are the best remedies, combined with general medical treatment.

I have seen what might be described as an epidemic of " spinal complaints" in a girls' school where the discipline was foolishly prudish and constrained, just as one often sees opidemics-epidemic because catching from one to anotherof laughing and crying and other hysterical outbreaks in the wards of a hospital.

\section{NOTES ON THE ETIOLOGY OF GOITRE.}

By H. C. L. MORRIS, M.D.Brox., L.R.C.P., M.R.C.S., Hambleden.

DURING two and a-half years' residence in Hambleden, Buckinghamshire, I have seen over 50 cases of goître in my practice-a strikingly large number out of a population of about 2,000; and 1 have little doubt that there are many more cases that have not come under my observations. The district is situated on and at the foot of the southernmost spurs of the Chiltern Hills. The soil is excessively chalky, and, with a few exceptions, the water supply is obtained from deep wells sunk into the chalk. When the springs are low the water is drawn up and even consumed while still milky in colour, for the poor take little trouble to boil or let it settle. I have met with no cases from the tops of the hills, where spring water is unattainable and the people drink stored rain water.

Of my 55 cases, all were water drinkers, only 4 being males, and the ages ranged from 4 to 76 . There seems to me to be little doubt that the presence of calcium and magnesium carbonates in the water is the sole cause of the disease in my cases. When the springs are high the water, tested by Clark's soap test, represents about 30 in 100,000 of total hardness, but when the springs are low the water is turbid, owing to the buckets disturbing the bottom of the wells.

The following instances are a little remarkable.

A girl, aged 23, who is in service in Jondon, invariably gets an enlargement of the thyroid about a week after she comes home, the enlargement disappearing shortly after her return to her situation.

In another case a family came to reside in this district, having previously lived on a clayey soil. Within six months three out of four children, aged 5, 7, and 8 years, presented thyroid enlargements. There was a little difficulty at first about these children, for I found that their water supply came from a rain water tank. I discovered, however, on making inquiries that the water they drank at school came from a chalk well, and was occasionally turbid. The fourth child, who did not attend school, showed no signs of the disease.

In several other instances new-comers have developed goitre shortly after settling in the neighbourhood.

I feel certain that heredity had nothing to do with the etiology of my cases, for in only one instance was there the slightest suspicion of it. Nor has intermarriage been a factor, for the one village in which the inhabitants have largely intermarried is, if anything, clearer of the disease than those round about it.

The amount of iron in the water is so infinitesimal that I think it can be left out of consideration. That goître may be produced by other causes in other places I think probable, but that it is produced in this neighbourhood solely by the carbonates of lime and magnesia in the drinking water I feel convinced.

Profressor Hrring, of Prague, has been appointed to the chair of Physiology in the University of Leipzig, vacant by the death of Professor Karl Ludwig.

THE annual festival of the Order of the Hospital of St. John of Jerusalem in England, was held on June 24th. After a religious service in St. John's Church, Clerkenwell, which has been restored, the original crypt of the old church of the Priory of the Order being preserved, the general assembly was held in the Charterhouse under the presidency of the Earl of Lathom.

\section{MEMORANDAi}

MEDICAL, SURGICAL, OBSTETRICAL, THERAPEUTICAL, PATHOLOGICAL, ETc.

\section{A CASE OF HYPERPYREXIA FOLLOWING IN FLUENZA.}

THe following case seems worthy of record both as regards the rarity of the complication in influenza, and also as being one of the highest temperatures on record in a non-hysterical pacient. Dr. Bryant, in a collection of 100 cases of hyperpyrexia published in the Guy's Hospital Reports for 1894, only quotes one higher temperature apart from pure hysteria, and that was in a hysterical patient suffering from phthisis, in which case the temperature rose to $128^{\circ}$.

A. W., aged 31, married, a publican, had been treated for intemperance. He was not of a hysterical type, and had generally enjoyed good health. From March 20 th to April 1st he was laid up with an attack of epidemic influenza similar to the present one except that his temperature never gave rise to any anxiety. The course run by the disease was quite normal. The profuse sweating with its accompanying rash of sudamina was a marked symptom. The recovery from this attack was complete.

On Aprll 15th he complained of feeling unwell, and was seen in the afternoon, when he had a temperature of $102.2^{\circ}$ The pulse was full, 90 . He was sent to bed and put on fluid diet, and ordered a mixture containing liquor ammonix acetatis. As in the previous attack, there was severe sweating, which produced the most marked rash of sudamina and miliaria that we had ever seen. The next day he was more comfortable, the temperature $101.4^{\circ}$, pulse 90 . On April 17th he was about the same, the temperature was $102^{\circ}$, on April 18 th $101^{\circ}$, and on April 19th $101^{\circ}$. On April 20th he was seen about 3 P.M., the temperature was $103^{\circ}$, the pulse 104; he was chatting perfectly rationally, and apparently in no different condition from what he had presented during the last. few days, except that the sweating had somewhat diminished. About 6 P.M. he became suddenly violent, requiring three people to hold him in bed. When seen a few minutes later he was quite unconscious, breathing stertorously; there was no corneal reflex; the pulse was extremely small, about 120 ; and the temperature was $110.2^{\circ}$ (twice taken) in the axilla. Ice was placed in each axilla, and the trunk and arms rubbed with it, but this was of no avail, and he died within a quarter of an hour of being seen.

He had never complained of pains in his joints, nor had he suffered from severe headaches; the lungs were quite free from physical signs on the afternoon of his death.

Dr. Rodman subsequently learnt that after his visit at. 3 P.M. On the day of his death the patient had expressed to his wife grave apprehensions of impending evil from his feverishness, from which he could not be dissuaded. He laid. great stress upon the fact of his having heard Dr. Rodman say as he went down stairs that his temperature was $103^{\circ}$, and higher than during the previous days.

The case was one of great interest, as within the space of at. the most three hours the temperature had risen upwards of seven degrees, and the history given points to the fact that it was only during the last half hour or so of his life that any symptom due to the existence of hyperpyrexia was noticed.

There were no symptoms to point to any pyæmic condition - for example, ulcerative endocarditis or meningitis.

Post mortem decomposition was exceedingly rapid. G. H. RODMAN, M.D.

East Sheen, S.W. ArThur C. Hovenden, M.B., B.S.Lond.

CONTROL OF HEMORRHAGE IN AMPUTATION AT THE SHOULDER-JOINT.

In recent numbers of the BrITISH MEDICAI Journat there have been articles by different. surgeons on various methods of controlling hæmorrhage in amputation at the shoulderjoint. I should like to mention a method which I adopted in 1891 , in a case of spreading traumatic gangrene of the arm. My method, I think, differs in some small degree from those already described. An elastic tourniquet was applied round the axilla and tied over the shoulder and an assistant's 